\title{
Extreme climatic phenomena and their impact in the shaping the current relief in the Bucegi-Leaota mountain complex
}

\author{
Ovidiu MURĂRESCU ${ }^{1}{ }^{*}$, George MURĂTOREANU ${ }^{1}$ and Mădălina FRÎNCULEASA ${ }^{1}$ \\ 1 Valahia University of Târgoviște \\ * Correspondence to: Ovidiu Murărescu, Valahia University of Târgoviște, Romania. E-mail: ovidiu_murarescu@yahoo.com.

\section{GEOREVIEW}

\section{Article history}

Received: April 2013

Received in revised form: July

2003

Accepted: August 2013

Available online: Sept. 2013

\begin{abstract}
The shaping of the current relief represents an important direction of study concerning the mountain areas, as these areas are some of the most dynamic relief units in Romania. A series of major relief changes are related to the spatial-temporal evolution and variability of the meteorological parameters that generate the climate features. A special impact in the shaping of the current high mountain areas is generated by the extreme climate phenomena (freezing, extreme precipitations, strong winds, the action of the snow, heat waves and cold waves, generated by the dynamics of the atmospheric circulation). The mountain complex Leaota-Bucegi is characterized, from this perspective, by a great variability of the climate parameters, and at present it includes three major tiers of relief that are being shaped: periglacial, fluvio-torrential and transitional.
\end{abstract}

KEY WORDS: extreme climate phenomena, periglacial, Leaota, Bucegi, shaping the current relief

\section{Introduction}

The shaping of the current relief the mountain complex Bucegi - Leaota has different features for each altitude tier. One can note the presence of the periglacial shaping system at the altitudes over $1800 \mathrm{~m}$, a system that imposes a typical relief, characterized by the presence of scree deposits, nival depressions and cryoturbations (frost churning). Here, the cryo-nival shaping processes are active, the most important of them being gelivation, nivation, cryoturbations, massive rock displacements, often combined to torrential erosion. In between 1600 and $1800 \mathrm{~m}$ there is a transitional tier where the action of the successive freezing and thawing and of the snow combines to fluvio-torrential shaping. The forested mountain tier is situated under the altitude of $1600 \mathrm{~m}$, in the area where the coniferous forest and the mixed foliage deciduous forest develop. The predominant types of erosion are the fluviatile erosion and the torrential one, which trigger gravitational processes.

Within these morphodynamic layers, extreme climate phenomena are particularly important as they trigger sudden changes of the environmental conditions and of the climate parameters. The most important extreme climate phenomena with implications in the shaping of the relief are snow avalanches, early frosts and late frosts, storms and torrential rains, strong winds. They 
often produce visible changes in the landscape, such as gelifraction phenomena, scree deposits, uprooted trees.

\section{Area under analysis}

The mountain complex Bucegi-Leaota represents the eastern extremity of the Meridional Carpathians, being situated in between Dâmboviţa and Prahova Valley (fig. 1). Following the major petrographic and structural differences, the periglacial forms of relief have been distributed differently among the two mountain units. The anticline made of crystalline schysts of the Leaota Mountains has generated nivally paved areas, seas of stone, nivation hollows on the quasi-horizontal surfaces, rivers of stone and small solifluction terraces on the slopes. One can notice the higher frequency of the relief forms developed on flat surfaces.

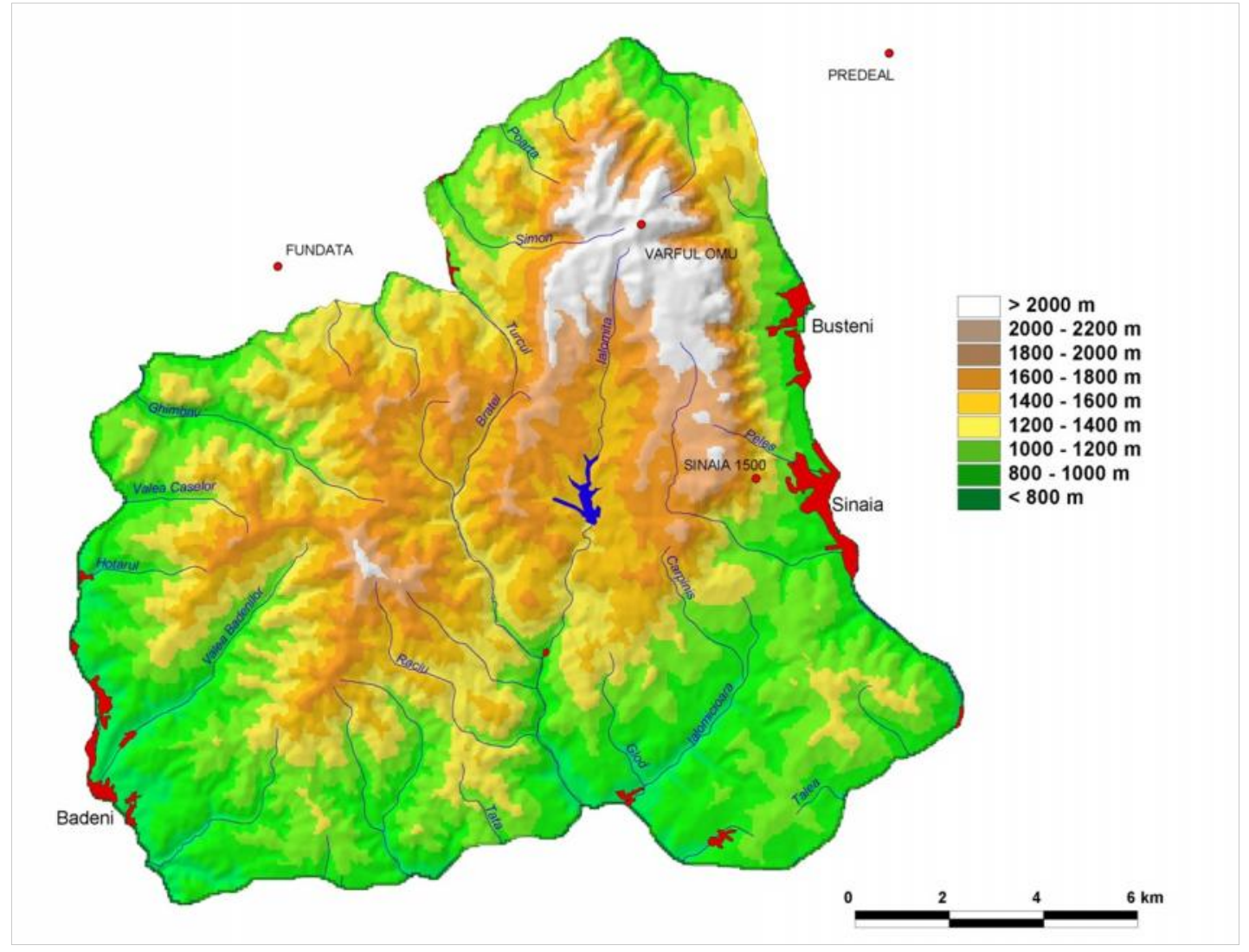

Figure 1. The Leaota - Bucegi mountain complex. This figure is available in colour online at www.georeview.ro.

The suspended syncline of the Bucegi Mountains filled with conglomerates and calcareous stones has generated mainly periglacial forms of relief on the inclined areas: sliding blocks and oscillating blocks, avalanche corridors with semi-funnels and nival horseshoes, solifluctions; however, there are also periglacial forms of relief developed on cvasi-horizontal surfaces: grassy molehills and nival niches. An important role in the appearance of the two categories of forms of 
relief has been played not just by the rock and the structure, but also by the different ancientness of the two mountain units (the older age of the Leaota Mountains) and implicitly the presence of leveled surfaces on much larger areas in the Leaota Mountains.

\section{Work methodology}

The meteorological data that lay at the basis of this study were taken over from the meteorological stations Vârful Omu (2505 m), Fundata (1370 m) and Sinaia (1505 m) (fig. 1).

The climate factors are expressed by: the gradients of the main meteorological elements, the amplitudes recorded by their values and the influence of the topoclimates. The temperature (especially its amplitude, its daily and seasonal oscillations and the freeze-thaw cycles) and the precipitations (especially torrential rains) are the most important elements.

Generally, in the Leaota-Bucegi mountain complex, there is a passage from the temperate morphoclimate system $(<1000 \mathrm{~m})$, to the periglacial relief shaping system (according to the Peltier diagrams), specific for higher altitudes (fig. 2).

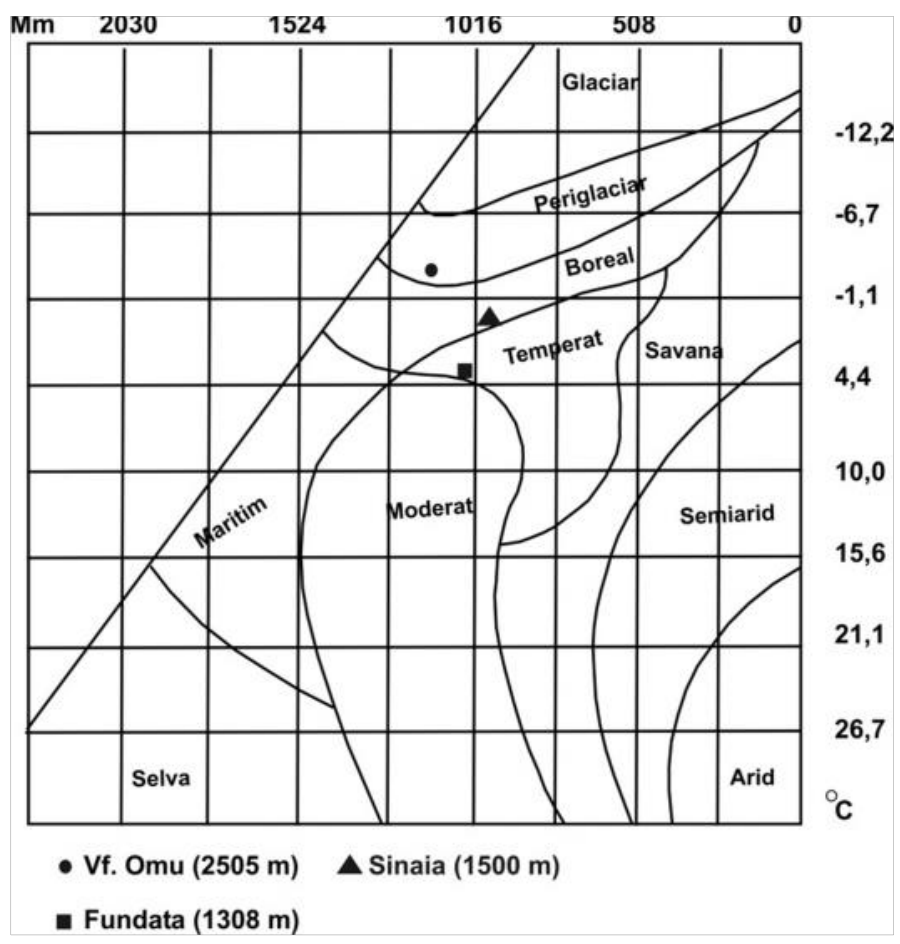

Figure 2. Morphoclimate systems expressed in Peltier diagrams (according to Urdea et al., 2002, with modifications).

The $3^{\circ} \mathrm{C}$ isotherm, which practically assures the passage from the periglacial shaping system (French 1996, quoted by Urdea et al., 2002) to the next one, is situated in the hypsometric interval $1600-1800 \mathrm{~m}$. Over this level, the climate is characterized by a significant high number of days with frost (Vârful Omu - 255 days), over 125 freeze-thaw cycles, large quantities of precipitations (1080 mm yr-1 at Vârful Omu), mainly in solid form (snow), leading to a number of 
150-210 days with snow layer. The thickness of the snow layer may range from 50 to $370 \mathrm{~cm}$ (Urdea et al., 2002).

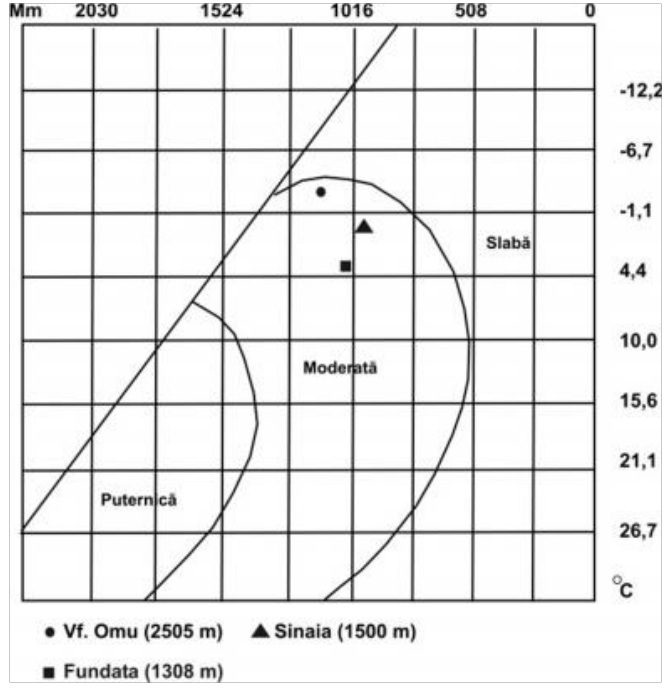

Chemical alteration

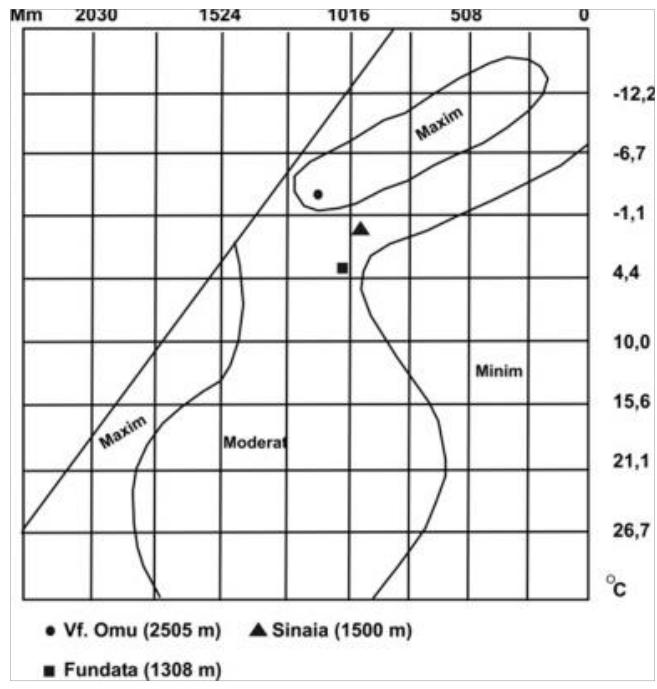

Massive rock displacements

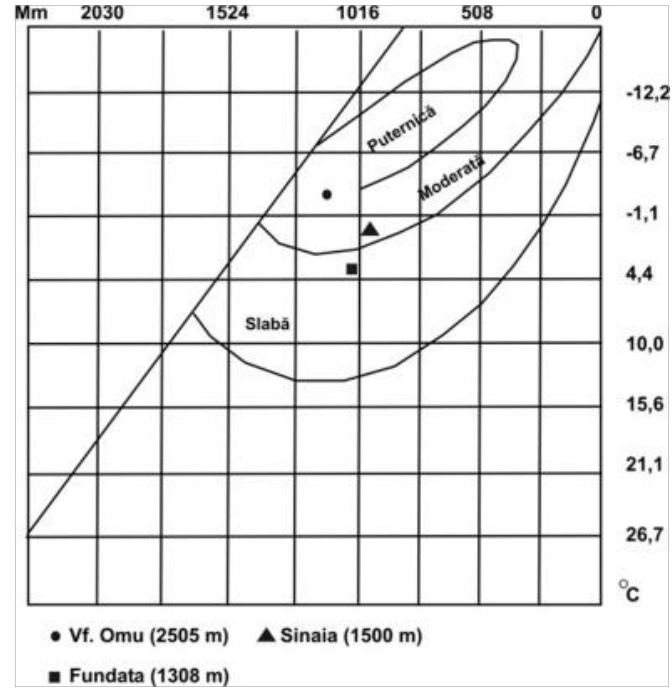

Gelifraction

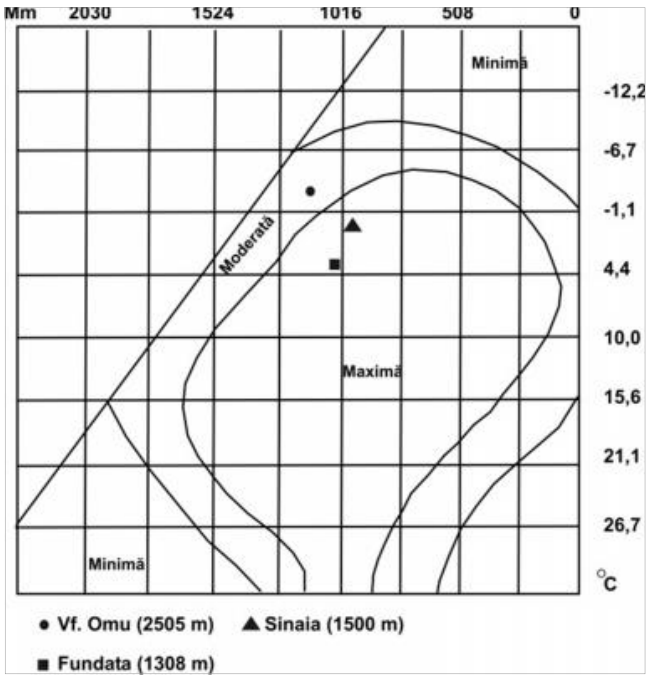

Fluviatile processes

Figure 3. The intensity of the current processes of relief shaping according to the altitude, expressed in Peltier diagrams (according to Urdea et al., 2002, with modifications)

The current geomorphological processes are diverse; they are carried out by means of a variety of agents and processes, the intensities of which vary depending on the geological, geomorphological and climate parameters and are adapted to the conditions of each morphodynamic tier (fig. 3). 
According to the Peltier diagrams, the intensity of the different geomorphological processes varies in relation with altitude. Consequently, the chemical alteration is moderate in the forested mountain tier and moderate to weak in the alpine tier; gelifraction is intense in the alpine tier and its intensity decreases towards the basis of the mountain; massive rock displacements are strongly present in the alpine tier and moderately present in the forested tier, while the fluviatile processes have a moderate weight in the area above the forested tier and a maximum weight in the forested tier

\section{Results}

The temperate alpine climate - an active factor in the shaping of the periglacial relief - occurs at altitudes over $1800 \mathrm{~m}$, above the upper limit of the forests. The features of the main climate elements need to meet the following requirements: the average monthly temperature must be under $0^{\circ} \mathrm{C}$ during 6-7 months a year; the annual average precipitations must be of $>1000 \mathrm{~mm}$.

In the alpine area of the Leaota-Bucegi mountains, the values of the average monthly temperatures are as follows: at the meteorological station from Omu Peak (Vârful Omu) (altitude: $2505 \mathrm{~m}$ ), 7 months of negative average temperatures are recorded, and the annual average temperature is of $-2.6^{\circ} \mathrm{C}$.

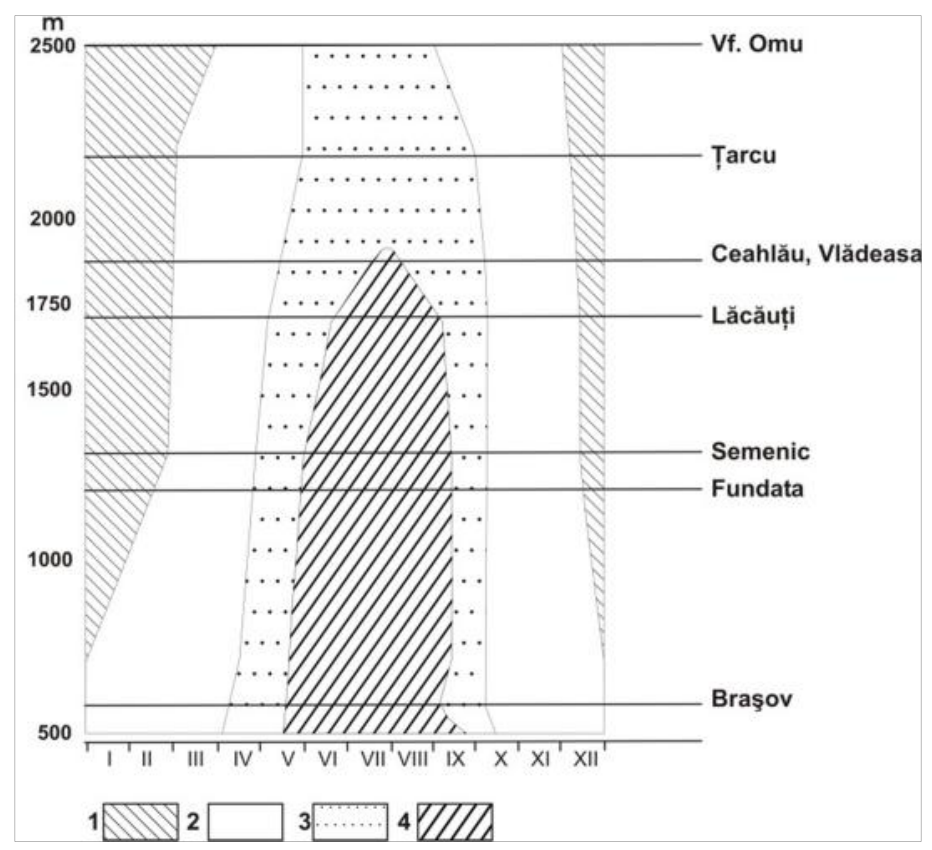

Figure 4. Intervals of occurrence of the freeze-thaw cycles in relation to the altitude. (according to Posea, Popescu, lelenicz, 1974): 1. Interval with a high frequency $(15-27)$ of the freeze-thaw cycles; 2. Interval with a low frequency of the freeze-thaw cycles (under 10); 3 . Interval with no or few freezethaw cycles; 4 . Warm interval, with no freeze-thaw cycles.

The precipitations recorded at the meteorological station Omu Peak (Vârful Omu) reach the value of $1080 \mathrm{~mm}$ per year. The values from Babele are not significant for the present study, because of the geographic position of this meteorological station. It is situated on the structural surface of the eastern cuesta (belonging to Prahova County) of the Bucegi Mountains, a location giving to 
this station a large wind exposure. This is why the precipitations are blown away by the wind, and the recordings of the pluviometers do not express the reality (Păun, 1998).

The cryonival processes are present in the alpine tier, a tier situated above the upper limit of the forest, where the harsh climate is characterized by the following values of the climate parameters (Loghin, 2002): average annual temperature $=-2.6-0^{\circ} \mathrm{C}$; number of the days with frost = 190-267; average annual number of the freeze-thaw cycles: 100, at altitudes over $1900 \mathrm{~m}$; average annual quantity of precipitations $=1200-1400 \mathrm{~mm}$; average duration of the snow layer $=$ 180-230 days. As far as the frequency of the freeze-thaw cycles is concerned (fig. 4), one can note the followings (Posea, et al., 1974): at altitudes over $1900 \mathrm{~m}$, the freeze-thaw cycles can appear during any period of the year; the existence of two periods (April-May and SeptemberOctober), at altitudes over $2200 \mathrm{~m}$, with a high frequency of the freeze-thaw cycles and of certain intervals during which freeze-thaw cycles are hardly encountered. It is under these conditions that the cryonival processes, specific for the alpine tier of the Romanian Carpathians, take place.

Gelivation reaches its maximum intensity during spring and autumn, when the most important daily thermal variations occur. Gelivation triggers gelifraction (the action of the frost on the rocks, leading to their disaggregation, affecting mainly the rocks situated at the surface). This generates disaggregation products: residual relief and till deposits (photo 1 ).

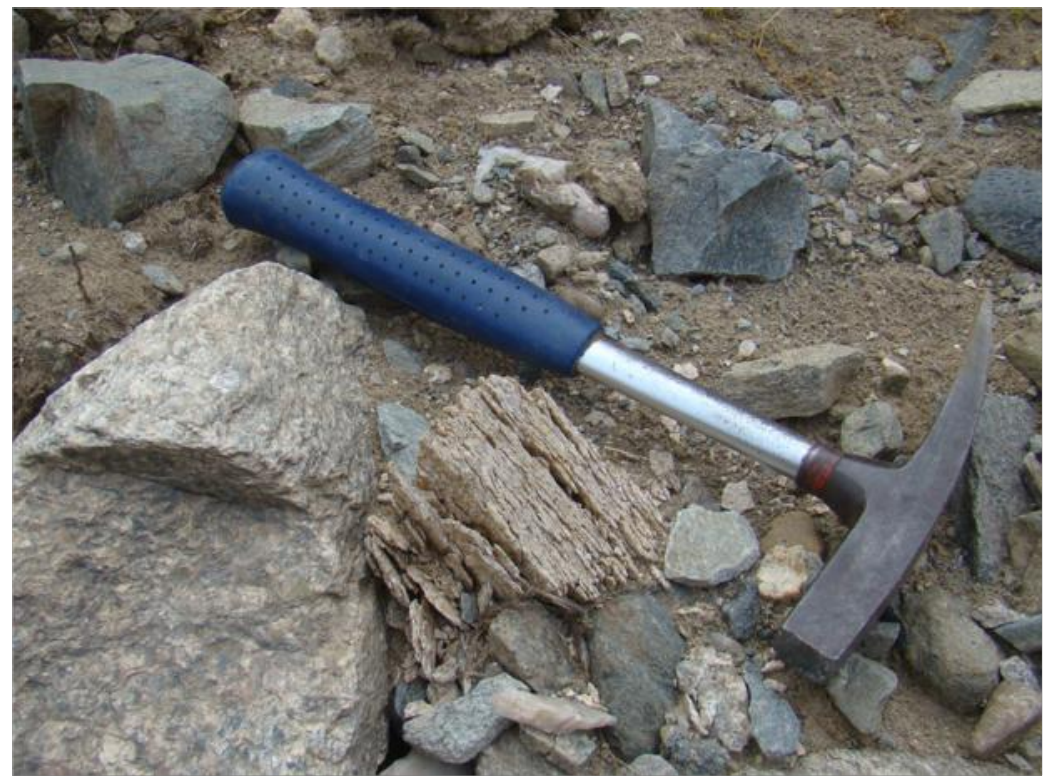

Photo 1. Gelifraction products on the left slope of lalomiţa valley, at an altitude of about $2400 \mathrm{~m}$.

Screes are typical especially in the Bucegi Massif, because of the conglomeratic and calcareous bedrock. Screes appear in correlation with the rock (at the basis of the abrupt slopes of the cuestas). Dimensions: areas from 20-40 m2 to 200-300 m2.

Oscillating blocks and sliding blocks are encountered at the basis of the structural slopes, on the glacis with a less marked slope that appears under them, and which has a regime of slow movement. In spring, when the ice and the snow melt and humidity reaches higher levels, the dynamics of these blocks is more evident. Around them appears a wave of colluvial materials and upstream from them, an elongated microdepression. Dimensions: from $0.5-1 \mathrm{~m}$ to $3-4 \mathrm{~m}$ diameter (photo 2). 


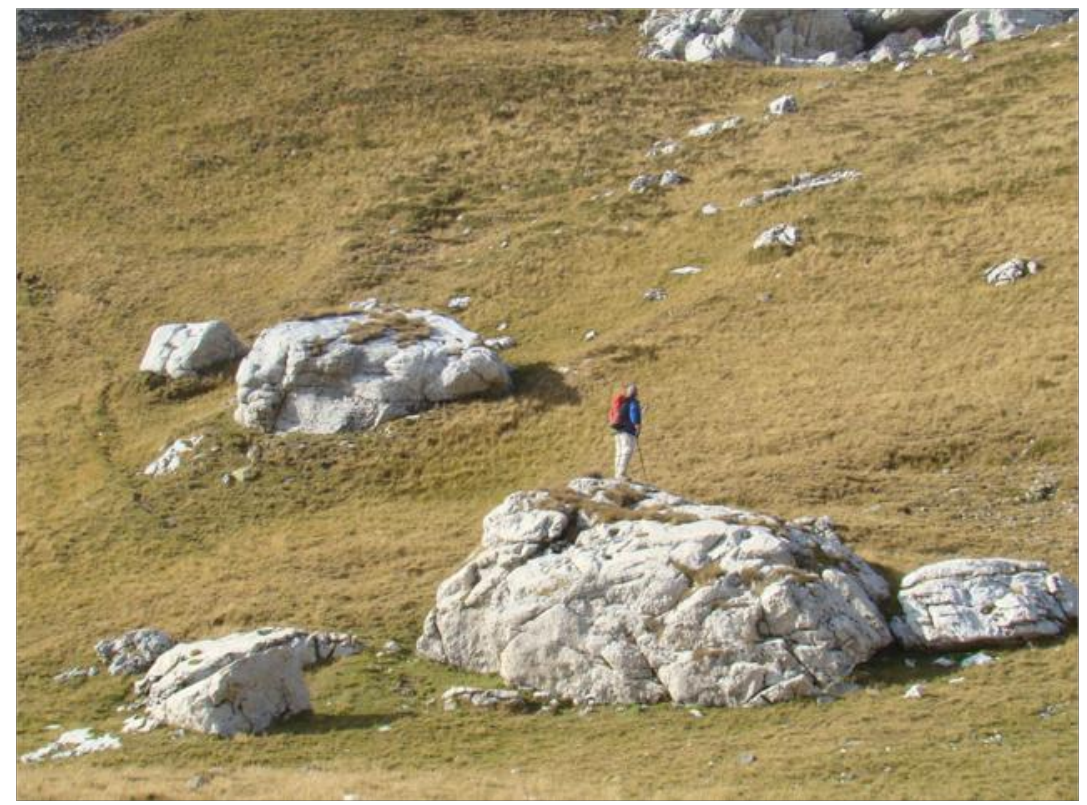

Photo 2. Sliding block in the glacial cirque of lalomiţa.

Avalanche corridors appear on the steep cuesta slopes following the occurrence of avalanches; in their final area, they present a deposit of materials whose shape is semicircular or conic. Dimensions: tens or hundreds of meters. They are associated with nival semi-funnels in the upper third of the slopes, in complex with the alignments of the avalanche corridors (constituting the upper part, which triggered them). They allow the accumulation of snow, which acts through compression and dissolution. Their shape is semicircular, more or less elongated. Dimensions: from $10-20 m$ to $80-100 m$ long (photo 3).

Grassy molehills (in Romanian: "marghilele") are deposits of fine material around an ice core or a block of rock. Dimensions: $10-20 \mathrm{~cm}-0.5 \mathrm{~m}$ in diameter.

Uprooted trees may leave behind a small mount. These mounts can appear after strong winds, generated when two air masses with different properties meet. Along the atmospheric front line, dynamic convective movements take place, generating cumulonimbus clouds, which in turn give birth to torrential precipitations often accompanied by electro-luminous phenomena and wind gust.

A series of such phenomena took place during the interval June 26-28, 2007, with an acme on June 27 (Vf. Omu and Fundata), when the maximum average speed of the wind was $34 \mathrm{~m} / \mathrm{s}$ $(122,4 \mathrm{~km} / \mathrm{h}$ ), with a maximum speed per gush of over $40 \mathrm{~m} / \mathrm{s}$ (over $144 \mathrm{~km} / \mathrm{h}$ ). The phenomenon was accompanied by torrential rain $(17.2 \mathrm{l} / \mathrm{m} 2$ in 24 hours) and associated with solid precipitations (small hail), during intervals of about 15 minutes in the morning (between 600 and 930 a.m.). At the same time, fog came in waves during several hourly intervals, and the minimum air temperature reached $5.10 \mathrm{C}$. During the following day, this succession of phenomena remained present, yet the intensity of the wind decreased to $80 \mathrm{~km} / \mathrm{h}$, and the minimum temperature went below $-1.50 \mathrm{C}$. Following these meteorological phenomena, several trees were uprooted in the upper basin of Ialomicioara from Leaota (photo 4). 


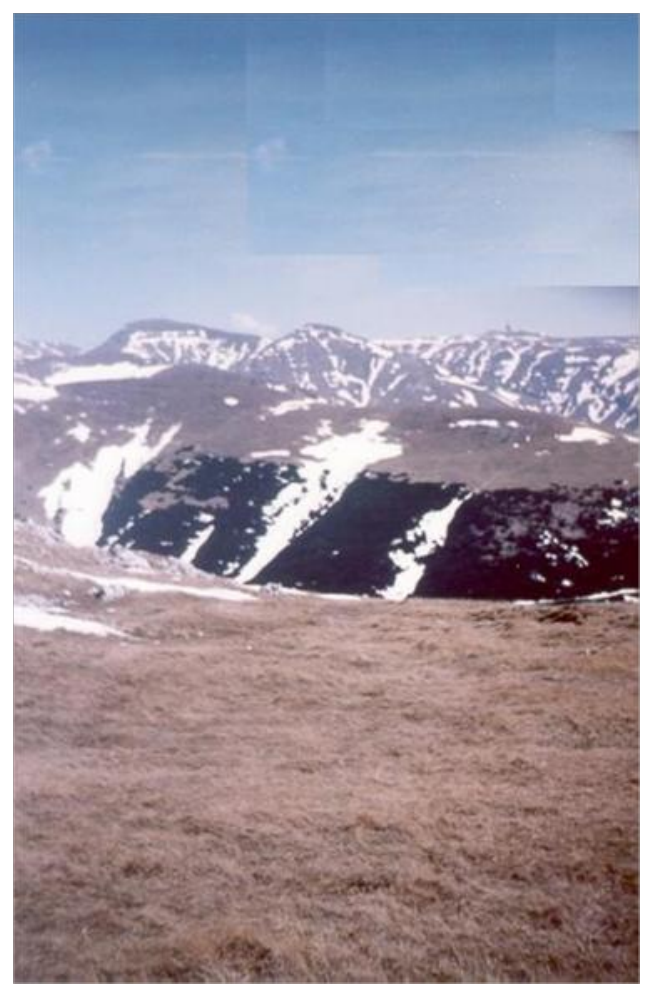

Photo 3. Avalanche corridors and nival semi-funnels on the left slope of lalomiţa valley. A view from Bătrâna Mountain.
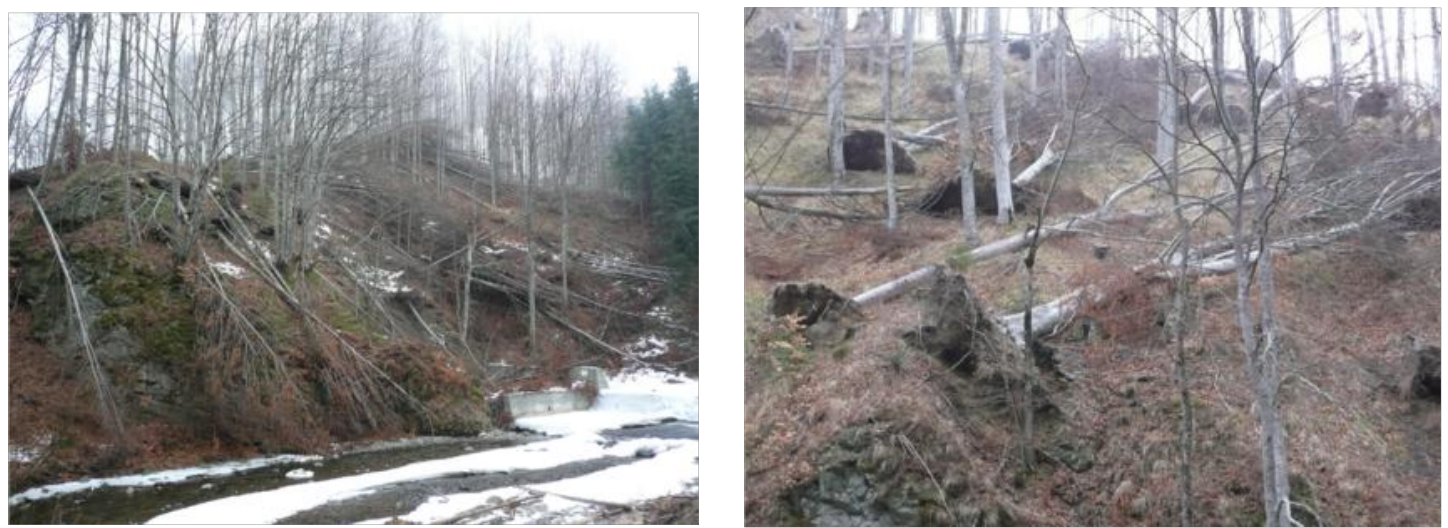

Photo 4. Uprooted trees in the upper basin of Ialomicioara from Leaota Mountain

\section{Conclusions}

The meteorological parameters influencing the shaping of the current relief at altitudes over $1600 \mathrm{~m}$ are the temperature (mainly the freeze-thaw cycles) and the precipitations, both through their duration and through their quantity and intensity. To these, one can add the accidental phenomena generated by the pressure and dynamics of the air masses (gusts of wind). 
Based on the analysis of a long data series of the meteorological parameters, one can create evolutionary models of the relief dynamics in the high alpine area (taking into account the cryonival and fluvio-torential shaping of the relief).

\section{References}

Loghin V. 2002. Modelarea curentă a reliefului şi degradarea terenurilor în bazinul lalomiţei, second edition, Edit. Cetatea de Scaun, Târgovişte.

Păun C. 1998. Carpaţii dintre Valea Dâmboviţei şi Valea Buzăului. Studiu climatologic, Edit. Macarie, Târgovişte.

Posea Gr., Popescu N., lelenicz M. 1974. Relieful României, Edit. Ştiinţifică, Bucureşti.

Urdea P., et al., 2002. Aspects of human geomorphological impact in mountain area of southern Carpathians, Carpato - Balkan Workshop Environmental change impacts in the CarpatoBalkan region, Croatia, poster. 